\title{
FOREIGN DIRECT INVESTMENT \\ IN LATIN AMERICA AND THE CARIBBEAN: AN EMPIRICAL ANALYSIS
}

\section{KEVIN WILLIAMS*}

\begin{abstract}
Competition for foreign direct investment (FDI) among developing countries has intensified in recent years. Using a sample of 68 developing countries across different regions, with data from 1975-2005, this paper investigates whether Latin America and the Caribbean (LAC) differs from non-LAC regions in regard to determinants of FDI; the evidence suggests that there are differences. In particular, the stock of infrastructure attracts FDI to LAC and constraints on the executive and high debt discourage FDI to non-LAC. These findings are robust to sample size, different estimators, endogeneity, and country fixed effects.
\end{abstract}

JEL classification: F21, O54, H63

Keywords: FDI, infrastructure, constraints on the executive, debt, Latin America and the Caribbean

\section{INTRODUCTION}

Developing countries have pursued a development agenda that is favorable to foreign direct investment (FDI) because of the potential benefits FDI is likely to generate for their economies. In particular, developing countries perceive FDI as a conduit for technology transfer, managerial know-how, access to foreign markets, and other "growthinducing" characteristics. For example, Kobrin (2005) suggests that over the period 1992-2001, 95\% of the economic reforms initiated by developing countries were favorable to FDI.

Latin America and the Caribbean (LAC), however, pursued protectionist economic policies in the 1950 s and 1960 s. In response to the first oil crisis of 1973-1974, the subsequent oil crisis of 1978-1979 and later the debt crisis of the 1980s, LAC countries began liberalizing their development strategies. Governments in the region, for example, have integrated their economies with the global economy by reducing trade barriers, privatizing state-owned enterprises, and removing controls on prices and capital accounts (Hernández and Parro, 2008). But has this

\footnotetext{
* Department of Economics, The University of the West Indies. Email: Kevin.Williams@sta.uwi.edu. I am grateful to the editor, Raimundo Soto, and an anonymous referee for insightful comments on an earlier draft of this paper. Any errors are, of course, my own.
} 
liberalization increased inflows of FDI beyond what would have been obtained in its absence, or does it simply motivate reallocation of the existing stock of FDI to earn greater profits (Gastanga et al., 1998)?

Today, many policymakers in the developing world seem to believe that FDI offers a source of foreign capital that supports their goal of achieving growth and this is reflected in vigorous policy competition to attract FDI. Developing countries demonstrate a great deal of confidence in FDI's ability to solve economic woes because it does not create debt and is long term (partially irreversible).

This paper investigates whether LAC is different from other developing countries in terms of the determinants of FDI, providing evidence that LAC and non-LAC differ in three important ways: the stock of infrastructure attracts FDI to LAC, while government debt and constraints on the executive discourage FDI to non-LAC. Two recent papers - Campos and Kinoshita (2008) and Kolstad and Villanger (2008) - look at data on FDI in LAC. In particular, Campos and Kinoshita (2008) examine the role of structural reforms in attracting FDI in a small sample of LAC and transition economies over a short time period. Kolstad and Villanger (2008) investigate whether Caribbean countries (excluding Latin America) are different from a sample of 135 countries.

The present study, however, departs from these studies in a number of ways: Instead of looking at transition economies, our dataset covers a broader set of developing countries, and we specifically investigate whether LAC is different in terms of the determinants of FDI compared to developing countries in general. Kolstad and Villanger (2008) use a simple OLS estimator and do not control for country fixed effects and endogeneity.

Studies that do not control for country fixed effects and endogeneity produce biased estimates that do not take into account variation in colonial heritage, institutions, and national policies, so to obtain reliable estimates it is important to control for these effects. This paper corrects for these biases by using more robust estimators to investigate whether LAC is different from developing countries overall.

The remainder of the paper is structured as follows: Section 2 presents FDI trends in LAC and reviews the empirical literature on FDI flows to LAC. Section 3 presents the data and the empirical specification, while the empirical results and discussion are contained in Section 4 and Section 5 concludes. 


\section{FDI TRENDS IN LAC AND EMPIRICAL Literature}

Table 1. FDI inflows to selected countries in LAC (USD millions) - 1970-2011

\begin{tabular}{lrrrr}
\hline Country & $\mathbf{1 9 7 0 - 7 9}$ & $\mathbf{1 9 8 0 - 8 9}$ & $\mathbf{1 9 9 0 - 9 9}$ & $\mathbf{2 0 0 0 - 1 1}$ \\
Argentina & 148.7 & 86.3 & 6813.1 & 5485.5 \\
Brazil & 1269.9 & 1721.3 & 9921.7 & 29563.5 \\
Chile & 64.5 & 481.3 & 3246.6 & 9279.75 \\
Colombia & 53 & 77.9 & 1870 & 6307.9 \\
Honduras & 8.2 & 25.4 & 86.1 & 620.67 \\
Mexico & 447 & 2070.8 & 8537.6 & 22910.9 \\
Peru & 40.7 & 31.5 & 1584.2 & 4052 \\
Uruguay & 44 & 52 & 116.1 & 1108 \\
Venezuela & 8.2 & 25.4 & 86.1 & 620.67 \\
\hline Source: United Nations Conference on Trade and Development $(2011)$. & \\
\hline
\end{tabular}

Table 1 reports annual average net FDI inflows to selected LAC economies since the implementation of market-oriented reforms. As is evident, these countries attract relatively large inflows, especially since the 1980s. The largest economies in LAC account for a disproportionate share of FDI inflows. For the three decades ending in 2011, the leading recipients of FDI inflows are Argentina, Brazil, Chile, and Mexico. Brazil, Mexico, and Chile are among the top 20 countries in the world receiving the greatest share of FDI flows in 2010.

As a region, LAC receives larger FDI inflows for the period 2005-2010 relative to other developing regions except for South, East and Southeast Asia. This is surprising, as U.S. FDI in LAC earns the lowest return (14\%) compared to Africa (30\%), Asia and the Pacific (21\%), and developing countries as a group (16\%) for 1991-1996 (Asiedu, 2002). FDI as a proportion of gross fixed capital formation is larger in LAC than in Asia (Wang, 2012). Recent trends of large inflows to LAC are explained by good economic performance and higher commodity prices (UNCTAD, 2011).

\subsection{Brief review of empirical literature on FDI in LAC}

The strategic proximity of LAC to the largest economy in the world (the U.S.) and its relative political stability make LAC an attractive market for U.S. FDI, an opportunity that was seized during the boom decade 
of the 1990s. The "China effect," however, seems to have had an impact on this trend, and policymakers in LAC have expressed fear of inflows being diverted to China. "The fear of PRC [People's Republic of China] is floating in the atmosphere here. It has become a challenge to the Americas not only because of cheap labor, but also on the skilled labor, technological and foreign investment fronts" (Cesar Gavin, Organization of American States; cited in Chantasasawat et al., 2004).

In contrast, Garcia-Herrero and Santabarbara (2005) argue that China has a small diversion effect on FDI flows to LAC, mostly affecting Mexico and Colombia during 2000 and 2001. The concern of policymakers in LAC therefore should not be for the region as a whole, but only for those two countries. Chantasasawat et al. (2004) suggest that policymakers should focus instead on economic growth, reducing corporate taxes, and linking their economies to the global economy, as these may offset China's influence on reducing FDI flows to LAC. And Galan and Gonzalez-Benito (2006) argue that the decision to place Spanish FDI in LAC is based on features unique to the region including shared cultural characteristics resulting from the region's colonial history.

Following economic reforms in LAC, Trevino et al. (2002) find that privatization exerts a positive effect on FDI inflows and this effect is persistent. Biglaiser and DeRouen (2006), however, find that financial and trade liberalization are more likely to explain FDI. Shatz (2001) asserts that the Andean group (Bolivia, Colombia, Ecuador, Peru, and Venezuela) attracts large FDI inflows (1994-1998) because policies toward FDI during the 1970s and 1980s became less restrictive. Hostility toward FDI had been influenced during the "core-periphery" debate in the 1950s and 1960s by LAC economists, many of whom argued in favor of an interventionist role for the state in economic development (Bengoa and Sanchez-Robles, 2003).

The evidence in De Gregorio (1992) suggests that FDI increases growth in LAC and the marginal contribution is greater relative to other types of investments. This is not surprising as FDI is relatively efficient. Moreover, FDI targeted to high-skilled industries has a greater probability of boosting growth (Alfaro and Charlton, 2007), while the wage differential between Mexico and the U.S. attracts U.S. FDI to Mexico (Love and Lage-Hidalgo, 2000).

None of these studies, however, investigates the potential differential effects of the determinants of FDI in LAC relative to a global sample 
of developing countries. The papers that come closest to the present study are Campos and Kinoshita (2008) and Kolstad and Villanger (2008). Again, what distinguish these studies from the present paper are sample composition and size, a particular emphasis, and methodology.

\section{DAta ANd Empirical Specification}

The data cover the period 1975-2005 inclusive, with a sample of 68 developing countries: 20 in LAC, 13 in Asia, 31 in sub-Saharan Africa (SSA), and 4 in North Africa. This time period was chosen due to the existence of large gaps in the data prior to 1975 for most of the variables for these countries. Information on the majority of the variables is based on published data from the World Bank's World Development Indicators (2006). We use the ratio of FDI to GDP (net FDI inflows) as the dependent variable, as is standard in the FDI literature. The following is a very brief explanation of the explanatory variables.

Following Aseidu (2002), Agiomirgianakis et al. (2006), and others, we use the ratio of imports and exports of goods and services to GDP to measure trade openness. The number of telephones per 1,000 people is used as a proxy for infrastructure (Campos and Kinoshito, 2003). GDP growth is used to measure the size of the domestic economy (Quartey and Tsikata, 2007). The ratio of government debt to GDP is used as a proxy for debt burden.

We use constraints on the executive as a proxy for good governance, from the Polity IV Project (2004). Constraints on the executive are based on a scale of 1 to 7: A higher score indicates more constraints (better governance). Revolution measures political instability (CrossNational Time Series Data Archive, 2003) and for macroeconomic stability, we use the annual change in consumer prices to capture inflation.

\subsection{Empirical specification}

We adopt an empirical model similar to that used in the literature to explore the determinants of FDI inflows (FDI/GDP) for a sample of developing countries, with a specific emphasis on LAC. The model takes the general form

$$
y_{i t}=\beta \lambda_{i t}+v_{i t}
$$


where the composite error is $v_{i t}=\alpha_{i}+\varepsilon_{i t}$ and $i$ and $t$ represent countries and time periods. $\alpha_{i}$ is unique to each unit (country), $\varepsilon_{i t}$ is idiosyncratic disturbances, $y_{i t}$ is the dependent variable, and $\lambda_{i t}$ is the vector of explanatory variables. We include $\alpha_{i}$ to control for unobserved country fixed effects. There is another important issue with Equation (1): If the unobserved country fixed effects are correlated with the vector of explanatory variables, fixed effects is the appropriate estimator. However, if there is no correlation between the unobserved country fixed effects and the vector of explanatory variables, random effects is the appropriate estimator. This can be assessed by using the Hausman test of no-correlation between the vector of explanatory variables and $\alpha_{i}$ (Wooldridge, 2009).

Specifically, the regression estimated is

$$
\begin{aligned}
\text { FDI } / \text { GDP }_{i t}= & \beta_{0} \text { Trade }_{i t}+\beta_{1} \text { Infrastructure } \\
& +\beta_{2} \text { Growth }_{i t}+\beta_{3} \text { Revolution }_{i t}+\beta_{4} \text { Debt }_{i t} \\
& +\beta_{5} \text { Constra int sonexecutive }_{i t}+\beta_{6} \text { Inflation }_{i t} \\
& +\alpha_{i}+\varepsilon_{i t}
\end{aligned}
$$

Initially, three econometric approaches are used to estimate Equation (2): pooled OLS, fixed effects (FE), and random effects (RE) with period averaged data for 1975-79, 1980-84, 1985-89, 199094, 1995-99, and 2000-05. The advantage of using period averages is to smooth out business cycle effects (Chitiga and Kandireo, 2003) and random year-on-year volatility. The analysis is then extended to address endogeneity concerns using lagged explanatory variables and a general method of moments (GMM) estimator. The paper implements an unbalanced panel, that is, there are missing observations for some countries and years, so the empirical results should be interpreted with caution.

\section{Empirical Results and Discussion}

The empirical analysis begins by using the full sample to investigate the determinants of FDI in developing countries. As a first step, pooled OLS, fixed effects (FE), and random effects (RE) estimators are used to estimate Equation (2). Concerns of potential endogeneity arising from the explanatory variables and the dependent variable are ignored. Later in the paper, the preferred estimator, GMM, is used to address 
endogeneity and to check the robustness of the determinants of FDI for the full sample. Finally, the robust determinants of FDI are then investigated to determine whether there are differences in terms of FDI between LAC and non-LAC. This approach is consistent with the main contribution of the paper, that is, to isolate differential effects of the determinants of FDI in LAC and non-LAC. Kolstad and Villanger (2008) and Asiedu (2002) follow a similar approach.

The results of the pooled OLS, fixed effects (FE), and random effects (RE) estimators are reported in Table 2.

Table 2. Determinants of FDI, entire sample of countries

\begin{tabular}{|c|c|c|c|}
\hline Independent variables & Pooled OLS & Fixed effects & Random effects \\
\hline Trade & $\begin{array}{c}0.024 \\
(0.000)^{* * *}\end{array}$ & $\begin{array}{c}0.017 \\
(0.002)^{* * *}\end{array}$ & $\begin{array}{c}0.022 \\
(0.000)^{* * *}\end{array}$ \\
\hline Debt & $\begin{array}{c}-0.002 \\
(0.737)\end{array}$ & $\begin{array}{c}-0.017 \\
(0.049)^{* *}\end{array}$ & $\begin{array}{c}-0.009 \\
(0.243)\end{array}$ \\
\hline Growth & $\begin{array}{c}0.121 \\
(0.000)^{* * *}\end{array}$ & $\begin{array}{c}0.161 \\
(0.000)^{* * *}\end{array}$ & $\begin{array}{c}0.143 \\
(0.000)^{* * *}\end{array}$ \\
\hline Infrastructure & $\begin{array}{c}0.004 \\
(0.001)^{* * *}\end{array}$ & $\begin{array}{c}0.004 \\
(0.000)^{* * *}\end{array}$ & $\begin{array}{c}0.004 \\
(0.000)^{* * *}\end{array}$ \\
\hline Inflation & $\begin{array}{c}6.1 \\
(0.956)\end{array}$ & $\begin{array}{c}-0.001 \\
(0.011)^{* *}\end{array}$ & $\begin{array}{c}-0.000 \\
(0.126)\end{array}$ \\
\hline Revolution & $\begin{array}{c}0.149 \\
(0.337)\end{array}$ & $\begin{array}{c}0.17 \\
(0.433)\end{array}$ & $\begin{array}{l}0.158 \\
(0.43)\end{array}$ \\
\hline Constraints on executive & $\begin{array}{c}0.046 \\
(0.338)\end{array}$ & $\begin{array}{c}0.007 \\
(0.902)\end{array}$ & $\begin{array}{l}0.028 \\
(0.55)\end{array}$ \\
\hline$F$-statistic & 16.15 & & \\
\hline Observations & 336 & 336 & 336 \\
\hline$R^{2}$ & 0.38 & & \\
\hline : within & & 0.31 & 0.3 \\
\hline :between & & 0.41 & 0.48 \\
\hline :overall & & 0.34 & 0.37 \\
\hline \multicolumn{4}{|c|}{$\begin{array}{l}\text { Notes: The dependent variable is FDI. P-values are in parentheses. }{ }^{* * *} \text { Significance at } 1 \% \text { level and } \\
* * \text { significance at } 5 \% \text { level. Estimates are based on robust standard errors. All specifications include } \\
\text { a constant. The Hausman test, } p \text {-value } 0.01 \text { and } \chi^{2} 17.39 \text {, is significant: fixed effects is preferred over } \\
\text { random effects. }\end{array}$} \\
\hline
\end{tabular}

Across the three estimators, only three variables are consistently significant determinants of FDI-trade, growth, and infrastructure-and all have the expected positive sign (with broadly similar coefficient estimates). Countries with higher trade volumes, faster growth, 
and larger stock of infrastructure attract more FDI. This is not a surprising result, and confirms previous findings. With fixed effects (as the preferred specification based on the Hausman test), inflation and government debt also appear significant with a negative sign, as expected. We must assess if these results are robust before considering the implications in terms of whether LAC is different from non-LAC.

Although fixed effects OLS is the preferred specification, it only accounts for unobserved country-specific factors; there is still the potential for endogeneity. This arises if a regressor in a model that is expected to determine the dependent variable is in turn determined by the dependent variable, or if both variables are jointly determined by a third unobserved variable. For example, FDI may be attracted to countries with good growth performance, but if growth is to be included as a determinant of FDI inflows it is important to control for potential endogeneity arising because FDI may itself have an impact on growth, or there may be an unobserved factor that affects both FDI and growth. The same applies to trade; that is, a country with a high trade volume may attract FDI and FDI in turn may determine its trade volume or both may be determined by a third variable such as the exchange rate.

Time-series data from developing countries is biased because of endogeneity (Chitiga and Kandiero, 2003). The authors address endogeneity with the generalized method of moments (GMM), using lagged regressors as instruments, due to Arellano and Bond (1991). Ndikumana and Verick (2007) address endogeneity with lagged (one period) explanatory variables. Lensink and Morrissey (2006) use both the 2SLS estimator and lagged explanatory variables to address potential endogeneity between FDI (and FDI volatility) and growth and find that lagged explanatory variables perform better (because, as is often the case, it is difficult to find suitable instruments).

Table 3 reports results using both lagged explanatory variables and GMM to control for potential endogeneity. In addition to providing valid internal instruments, GMM controls for country fixed effects (Cameron and Trivedi, 2006). The validity of the instruments can be assessed with the Hansen/Sargan test of over-identifying restrictions (OIR), with a chi-square distribution under the null that the OIR is valid and there is no-second order serial correlation in the residuals, providing an additional check of the model specification. Specifically, a $p$-value above 0.05 for both the OIR and no-second order serial correlation in the disturbances suggest that the instruments are valid and the model is correctly specified (Cameron and Trivedi, 2006). 
Table 3. Determinants of FDI, entire sample of countries

\begin{tabular}{|c|c|c|c|c|}
\hline Independent variables & Pooled OLS & Fixed effects & $\begin{array}{c}\text { Random } \\
\text { effects }\end{array}$ & GMM \\
\hline Trade $_{t-1}$ & $\begin{array}{c}0.021 \\
(0.000)^{* * *}\end{array}$ & $\begin{array}{l}0.005 \\
(0.53)\end{array}$ & $\begin{array}{c}0.017 \\
(0.000)^{* * *}\end{array}$ & $\begin{array}{c}0.012 \\
(0.422)\end{array}$ \\
\hline Debt & $\begin{array}{l}-0.009 \\
(0.199)\end{array}$ & $\begin{array}{c}-0.042 \\
(0.000)^{* * *}\end{array}$ & $\begin{array}{c}-0.022 \\
(0.013) * *\end{array}$ & $\begin{array}{c}-0.045 \\
(0.015)^{* *}\end{array}$ \\
\hline Growth $_{t-1}$ & $\begin{array}{l}0.024 \\
(0.46)\end{array}$ & $\begin{array}{c}0.036 \\
(0.305)\end{array}$ & $\begin{array}{c}0.03 \\
(0.341)\end{array}$ & $\begin{array}{c}0.357 \\
(0.000)^{* * *}\end{array}$ \\
\hline Infrastructure & $\begin{array}{c}0.004 \\
(0.001)^{* * *}\end{array}$ & $\begin{array}{c}0.004 \\
(0.000)^{* * *}\end{array}$ & $\begin{array}{c}0.004 \\
(0.000)^{* * *}\end{array}$ & $\begin{array}{c}0.003 \\
(0.090)^{*}\end{array}$ \\
\hline Inflation & $\begin{array}{c}-0.000 \\
(0.193)\end{array}$ & $\begin{array}{c}-0.001 \\
(0.000)^{* * *}\end{array}$ & $\begin{array}{c}-0.001 \\
(0.024)^{* *}\end{array}$ & $\begin{array}{c}-0.001 \\
(0.004)^{* * *}\end{array}$ \\
\hline Revolution & $\begin{array}{c}0.118 \\
(0.514)\end{array}$ & $\begin{array}{c}0.044 \\
(0.859)\end{array}$ & $\begin{array}{c}0.081 \\
(0.732)\end{array}$ & $\begin{array}{c}0.652 \\
(0.251)\end{array}$ \\
\hline Constraints on executive & $\begin{array}{c}0.081 \\
(0.141)\end{array}$ & $\begin{array}{c}-0.03 \\
(0.685)\end{array}$ & $\begin{array}{c}0.048 \\
(0.398)\end{array}$ & $\begin{array}{c}-0.393 \\
(0.027)^{* *}\end{array}$ \\
\hline$F$-statistic & 11.37 & & & \\
\hline Observations & 290 & 290 & 290 & 270 \\
\hline$R^{2}$ & 0.3 & & & \\
\hline : within & & 0.25 & 0.22 & \\
\hline : between & & 0.17 & 0.39 & \\
\hline : overall & & 0.19 & 0.29 & \\
\hline $\operatorname{AR}(1)$ & & & & 0.001 \\
\hline $\operatorname{AR}(2)$ & & & & 0.34 \\
\hline Hansen Test & & & & 0.61 \\
\hline \multicolumn{5}{|c|}{$\begin{array}{l}\text { Notes: Dependent variable is FDI/GDP. P-values are in parentheses. } * * * \text { Significance at } 1 \% \text { level, } * * \\
\text { significance at } 5 \% \text { level, and significance at } 10 \% \text { level. Estimates are based on robust standard errors. } \\
\text { GMM includes full time indicators. The AR(2) test of no-second order serial correlation does not reject } \\
\text { the null and the Hansen test is used for over-identifying restrictions, which suggests the instruments are } \\
\text { valid and hence the model is correctly specified. AR(1) is the test of no-first order serial correlation, } \\
\text { indicating first order serial correlation, as expected. The Hausman test, } p \text {-value } 0.00 \text { and } \chi^{2} 23.93 \text {, is } \\
\text { significant: fixed effects is preferred. All specifications have a constant. }\end{array}$} \\
\hline
\end{tabular}

Estimates are for the full sample with trade and growth lagged (one period) in pooled OLS, fixed effects, and random effects for comparison with Table 2; in general, the results are weaker and infrastructure is significant across all three methods with the expected sign. As GMM is our preferred method, we focus on those results.

For GMM debt, inflation, infrastructure (weakly), growth, and constraints on the executive are significant and all except constraints on the executive have the expected sign; trade is insignificant, as is revolution. The $\operatorname{AR}(2)$ test of no-second order serial correlation and the Hansen statistic of 
over-identifying restrictions suggest that the instruments are valid and the model is correctly specified. Insofar as the lags are valid instruments and the GMM controls for unobserved country-specific factors, it gives relatively efficient estimates and is therefore the preferred estimator. Thus, FDI appears to be attracted to countries exhibiting growth, with physical infrastructure and macroeconomic stability (relatively low inflation and debt-servicing costs).

The most surprising result is that the coefficient on constraints on the executive is negative: Good governance or rules-based institutions as measured by constraints on the executive appear to discourage FDI in the full sample of developing countries. This negative result may occur because we could not control for the type of FDI; for example, foreign investment attracted by natural resources or privatization may be less subject to concerns about governance than market-seeking FDI or investment for manufactured exports. It is possible that in some developing countries with low values for positive determinants of FDI (growth, infrastructure, and macroeconomic stability) but which have other features attractive to FDI (such as resources-these are not country-specific as they are present in a range of countries), constraints on the executive tend to be relatively low and hence this variable picks up these FDI-attracting features across a number of countries.

The values of the principal determinants (growth, infrastructure, and macroeconomic stability) explain much of the cross-country variation in FDI inflows, in particular investment for manufactures (market-seeking or export-oriented); countries with high values of these variables may also tend to have relatively significant constraints on the executive. Other features that are attractive to FDI, such as natural resources or large-scale privatization, may tend to be present in countries with relatively low values of the principal determinants and relatively weak governance (low constraints on the executive). Thus, conditional on principal determinants, low constraints on the executive capture FDI motivated by other features.

This negative relationship with constraints on the executive supports the finding by Quartey and Tsikata (2007). Kolstad and Villanger (2008) also find a negative correlation between FDI and regulation quality in the Caribbean. High levels of debt and high inflation discourage FDI: A heavily indebted host country increases the risk of expropriation and restrictions on profit repatriation, while high and variable inflation make future profits uncertain, so foreign investors 
are likely to consider these variables when looking at locations. These findings are supported by many studies, but contradict others that plausibly argue that the willingness of foreign investors to invest in developing countries with significant debt and high inflation is due to the high rates of return obtained, after adjusting for these distortions. High rates of return on investments (typically natural resources) also explain why FDI flows to violent and corrupt regimes.

\subsection{Is LAC different?}

Having identified potential determinants in the full sample of developing countries, in this section we investigate the main question of the paper: Is LAC different from other developing countries in terms of the determinants of FDI? To address this question, we interact a LAC dummy with the determinants that are significant in the most robust estimator-GMM-although we check the results with fixed effects and random effects. Results are reported in Table 4.

Infrastructure is positive and significant in LAC, suggesting that the stock of infrastructure attracts FDI in LAC, while infrastructure is insignificant in non-LAC, suggesting that the stock of infrastructure is not a determinant in non-LAC. ${ }^{1}$ Constraints on the executive have a negative and significant effect on FDI inflows to non-LAC, and while the coefficient is positive for LAC, it is not significant at conventional levels in the GMM specification.

Constraints on the executive in the full sample (Table 3, GMM) is negative, but is positive for LAC and negative for non-LAC in Table 4. The change in sign may be due to measurement error, but constraints on the executive are often used to measure governance ${ }^{2}$ and the specification closely follows the FDI literature. Moreover, given that we have averaged the data over 5-year periods, "some measurement errors wash out in time averages" (Mulligan et al., 2004: 62). The likely reason, however, for the difference is that because Table 3 contains determinants for the full sample, it masks differences between LAC and non-LAC. These differences are highlighted when LAC is interacted with determinants in Table 4 (this is supported when we construct subsamples for LAC and non-LAC in Table 5 below).

1. In the appendix we experiment with an Asian dummy interacted with determinants as in Table 4, and the results are somewhat weaker.

2. See Acemoglu, Johnson, and Robinson (2002) and Asiedu (2002). 
Table 4. Determinants of FDI in LAC and non-LAC

\begin{tabular}{|c|c|c|c|}
\hline Independent variables & Fixed effects & Random effects & GMM \\
\hline Trade $_{t-1}$ & $\begin{array}{l}0.009 \\
(0.23)\end{array}$ & $\begin{array}{c}0.02 \\
(0.000)^{* * *}\end{array}$ & $\begin{array}{c}0.019 \\
(0.267)\end{array}$ \\
\hline Debt & $\begin{array}{c}-0.054 \\
(0.000)^{* * *}\end{array}$ & $\begin{array}{c}-0.048 \\
(0.000)^{* * *}\end{array}$ & $\begin{array}{l}-0.028 \\
(0.34)\end{array}$ \\
\hline Growth $_{t-1}$ & $\begin{array}{c}0.024 \\
(0.549)\end{array}$ & $\begin{array}{c}0.023 \\
(0.519)\end{array}$ & $\begin{array}{c}0.163 \\
(0.167)\end{array}$ \\
\hline Infrastructure & $\begin{array}{l}0.000 \\
(0.97)\end{array}$ & $\begin{array}{c}0.000 \\
(0.679)\end{array}$ & $\begin{array}{l}-0.004 \\
(0.215)\end{array}$ \\
\hline Inflation & $\begin{array}{l}-0.009 \\
(0.218)\end{array}$ & $\begin{array}{c}0.003 \\
(0.662)\end{array}$ & $\begin{array}{c}0.014 \\
(0.282)\end{array}$ \\
\hline Revolution & $\begin{array}{c}0.058 \\
(0.813)\end{array}$ & $\begin{array}{c}0.165 \\
(0.458)\end{array}$ & $\begin{array}{c}0.504 \\
(0.266)\end{array}$ \\
\hline Constraints on executive & $\begin{array}{c}-0.167 \\
(0.080)^{*}\end{array}$ & $\begin{array}{c}-0.095 \\
(0.178)\end{array}$ & $\begin{array}{c}-0.448 \\
(0.039)^{* *}\end{array}$ \\
\hline Debt $\times$ LAC & $\begin{array}{c}0.032 \\
(0.152)\end{array}$ & $\begin{array}{c}0.05 \\
(0.004)^{* * *}\end{array}$ & $\begin{array}{c}0.004 \\
(0.879)\end{array}$ \\
\hline Infrastructure $\times \mathrm{LAC}$ & $\begin{array}{c}0.006 \\
(0.001)^{* * *}\end{array}$ & $\begin{array}{c}0.006 \\
(0.000)^{* * *}\end{array}$ & $\begin{array}{c}0.005 \\
(0.031)^{* *}\end{array}$ \\
\hline Growtht- $1 \times$ LAC & $\begin{array}{c}0.03 \\
(0.688)\end{array}$ & $\begin{array}{c}0.062 \\
(0.357)\end{array}$ & $\begin{array}{c}0.071 \\
(0.672)\end{array}$ \\
\hline Inflation $\times \mathrm{LAC}$ & $\begin{array}{c}0.008 \\
(0.271)\end{array}$ & $\begin{array}{l}-0.003 \\
(0.601)\end{array}$ & $\begin{array}{l}-0.015 \\
(0.245)\end{array}$ \\
\hline Constraints on executive $\times \mathrm{LAC}$ & $\begin{array}{c}0.267 \\
(0.071)^{*}\end{array}$ & $\begin{array}{c}0.266 \\
(0.029)^{* *}\end{array}$ & $\begin{array}{l}0.319 \\
(0.27)\end{array}$ \\
\hline LAC & & $\begin{array}{c}-2.168 \\
(0.010)^{* * *}\end{array}$ & \\
\hline Observations & 290 & 290 & 270 \\
\hline \multicolumn{4}{|l|}{$R^{2}$} \\
\hline : within & 0.3 & 0.28 & \\
\hline : between & 0.29 & 0.54 & \\
\hline : overall & 0.25 & 0.39 & \\
\hline $\operatorname{AR}(1)$ & & & 0.01 \\
\hline $\operatorname{AR}(2)$ & & & 0.3 \\
\hline Hansen Test & & & 0.18 \\
\hline \multicolumn{4}{|c|}{$\begin{array}{l}\text { Notes: Dependent variable is FDI/GDP. LAC is a }(1,0) \text { dummy for Latin America and the Caribbean } \\
\text { We used variables that are statistically significant in the preferred specification (GMM) from Table } \\
\text { (to interact with LAC dummy). GMM includes full time indicators. All specifications have a constant } \\
\text { The AR(2) test and the Hansen tests support the GMM specification. The Hausman test, } p \text {-value } 0.0 \\
\text { and } \chi^{2} 34.98 \text {, is significant: fixed effects is preferred. Estimates are based on robust standard errors. } \\
P \text {-values are in parentheses. }\end{array}$} \\
\hline
\end{tabular}


One interpretation of the negative coefficient on constraints on the executive in non-LAC is that democratic institutions in these countries are relatively poor and therefore protection of property rights are nonexistent or unlikely to be enforced. Poor democratic institutions increase the risk of expropriation and discourage FDI inflows to non-LAC. Poor governance (high risk of expropriation) in developing countries likely explains the disproportionate flows of FDI to developed countries. The positive coefficient on constraints on the executive for LAC provides some evidence (weakly), however, that better governance in LAC provides greater incentives for foreign investors. This is supported by Bai et al. (2013) who argue that decisions by firms in Vietnam to relocate across provinces are influenced by the quality of governance.

There is some evidence of a negative and significant effect for government debt in non-LAC, although the coefficient is insignificant (at conventional levels) in the preferred specification, GMM. Developing countries with poor governance are likely to have high government debt, as political elites who face few constraints on spending fiscal resources are likely to pursue unsustainable debt. The estimate is consistent with the hypothesis: Low governance in non-LAC also suggests high government debt which in turn increases the risk of expropriation.

The estimate for government debt is positive for LAC but insignificant in the GMM specification, suggesting that FDI inflows in LAC may be indifferent to government debt. ${ }^{3}$ This could be the case if investors believe that property rights are secure, or if the risk-adjusted rates of return on their investments are relatively high. The evidence is consistent with Agosin and Machado (2007) who argue that LAC has gone the furthest in implementing policies favorable to FDI since the 1980s, while Asia is selective in its FDI regimes, a practice that is absent in LAC. Taken together, does this mean that LAC is different from non-LAC in terms of the determinants of FDI?

Thus far the evidence suggests that the answer is yes, but we check the robustness of the results in Table 5. We construct two subsamples of 20 (LAC) and 48 (non-LAC) countries. The size of these subsamples renders the use of the GMM estimator infeasible, as "the GMM estimators are asymptotically biased in a small sample" (Campos and Kinoshita, 2003). Again, we use random effects and fixed effects with potential endogenous variables (trade and growth) lagged one period. Table 5 reports results for both LAC and non-LAC. 


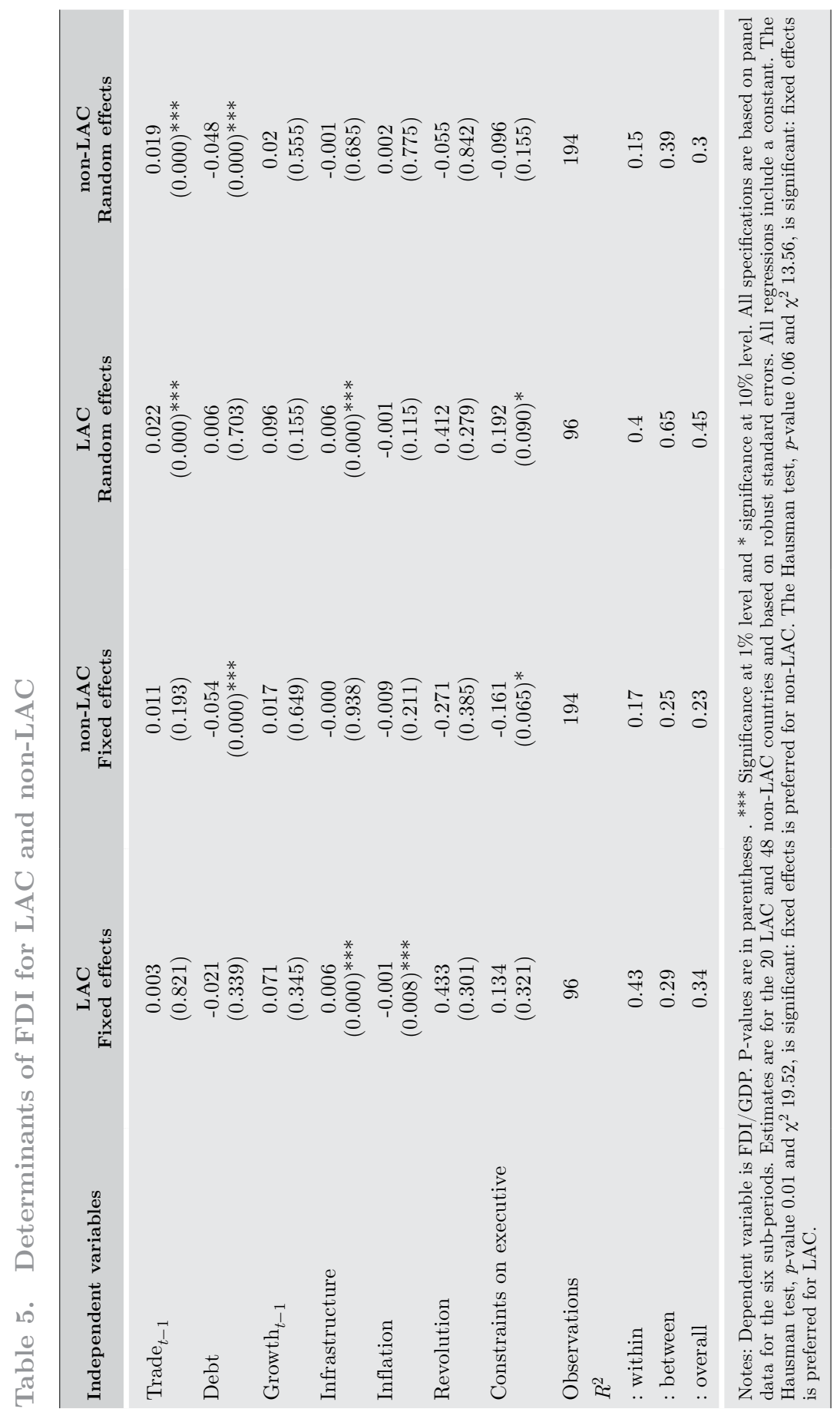


Constraints on the executive retains its sign and significance for both LAC and non-LAC from Table 4; that is, FDI is negatively correlated with constraints on the executive in non-LAC, while there is a positive association with FDI in LAC. These effects are economically large. For example, the estimate of 0.192 (column 3) implies that a $10 \%$ higher score for constraints on the executive is typically associated with a $2 \%$ increase in FDI inflows in LAC. In contrast, a $10 \%$ higher score for constraints on the executive (column 2 ) is associated with a $2 \%$ reduction in FDI inflows in non-LAC. The negative coefficient of constraints on the executive in non-LAC provides further evidence that the negative correlation between constraints on the executive and FDI in Table 3 is driven by non-LAC. Government debt is also negative and significant and the size of the estimate is the same as in Table 4 for non-LAC. The magnitude of the estimate- 0.054 (column 2)-suggests that a $10 \%$ increase in the size of government debt reduces FDI inflows by $0.54 \%$ in non-LAC. The stock of infrastructure attracts FDI inflows to LAC, implying that a $10 \%$ increase in the number of telephones per 1,000 people is associated with a $0.06 \%$ increase in FDI inflows. There is some evidence of an effect for inflation and trade in LAC and non-LAC, although these effects are not robust.

Following Paternoster et al. (1998), a test of equality of coefficients (columns 1 and 2) finds that infrastructure is the most robust determinant of the differences in FDI inflows to LAC and non-LAC (z-test of 4.17 with p-value 0.00 rejects the null of equal effect in both regressions). ${ }^{4}$ A test of equal effect across regressions for government debt and constraints on the executive for LAC and non-LAC is statistically insignificant at conventional levels.

Based on the empirical analysis and the preceding discussion, there is evidence that LAC and non-LAC are different in terms of the determinants of FDI. The stock of infrastructure is likely to attract FDI in LAC, but there is no evidence of an effect for non-LAC. Constraints on the executive discourage FDI inflows to non-LAC, and there is evidence of a positive effect for LAC. Finally, high debt is likely to discourage FDI inflows to non-LAC, but does not seem to matter for FDI inflows to LAC.

4. This test is computed as follows: $z=0.006-0.0001 / \sqrt{(0.001)^{2}+(0.001)^{2}}$. LAC: estimate 0.006, s.e. 0.001 ; non-LAC: estimate 0.0001 , s.e. $=0.001$. 


\section{ConCluding Remarks}

Because FDI inflows bring perceived advantages, policymakers in the developing world have taken an accommodating stance, competing to attract FDI. This paper investigates whether LAC is different from non-LAC in terms of the determinants of FDI inflows. In particular, the main findings suggest that the stock of infrastructure attracts FDI inflows to LAC, high debt discourages FDI inflows to non-LAC, and constraints on the executive discourage FDI inflows to non-LAC. This evidence suggests that LAC is different from non-LAC in regard to the determinants of FDI in at least three dimensions.

The implication of these findings is that LAC governments could have an advantage over other developing countries in attracting FDI by focusing not only on expanding the stock of infrastructure but also its quality. Because exports are important to the region's economic success, LAC countries should incorporate seaport and airport infrastructure development into their overall infrastructure goals to take full advantage of international markets. Infrastructure development in general suggests one channel through which policymakers in LAC can improve the welfare of their countries by attracting greater levels of FDI inflows. Furthermore, "public investments in infrastructure (e.g., water, sanitation, roads, ports, and power grids) are vital to support growing cities" (McCord and Sachs, 2013: 09). This is even more important, as debt does not appear to constrain FDI to LAC and foreign investors seem to believe that their property rights are likely to be protected in the region.

Because an investigation of FDI inflows at the industry level was beyond the scope of this paper, we are not able to determine which industries are likely to be affected by the determinants that differentiate LAC from non-LAC. One approach for future study is to examine the determinants of FDI at the industry level and test whether there is heterogeneity across regions (although we suggest that poor governance may not discourage FDI attracted by natural resources, we did not investigate that hypothesis). 


\section{REFERENCES}

Acemoglu, D., S. Johnson, and J. Robinson (2002), "Reversal of fortune: Geography and institutions in the making of the modern world income distribution," Quarterly Journal of Economics 117(4): 1231-94.

Agiomirgiankis, G., D. Asteriou, and K. Papathoma (2006), "The determinants of foreign direct investment: A panel data study for OECD countries," Discussion Paper 03, City University of London, Department of Economics.

Agosin, M. and R. Machodo (2007), "Openness and the international allocation foreign direct investment," Journal of Development Studies 43(7): 1234-47.

Alfaro, L. and A. Charlton (2007), "Growth and the quality of foreign direct investment: Is all FDI equal?" Centre for Economic Performance Discussion Paper 830, London School of Economics and Political Science.

Asiedu, E. (2002), "On the determinants of foreign direct investment to developing countries: Is Africa different?" World Development 30(1): 107-19.

Bai, J., S. Jayachandran, E. J. Malesky, and B.A. Olken (2013), "Does economic growth reduce corruption? Theory and evidence from Vietnam," Massachusetts Institute of Technology Working Paper.

Banks, A.S. and K. A. Wilson (2003), Cross-National Time-Series Data Archive. Databanks International. Jerusalem, Israel, (http://www. databanksinternational.com).

Bengoa, M. and B. Sanchez-Robles (2003), "Foreign direct investment, economic freedom and growth: New evidence from Latin America," European Journal of Political Economy 19(3): 529-45.

Biglaiser, G. and K. DeRouen (2006), "Economic reforms and inflows of foreign direct investment in Latin America," Latin America Research Review 41(1): 51-75.

Cameron, A.C. and P.K. Trividi (2006), Microeconometrics: methods and applications. New York: Cambridge University Press.

Campos, N.F. and Y. Kinoshita (2008), "Foreign direct investment and structural reforms: Evidence from Eastern Europe and Latin America," International Monetary Fund Working Paper 08/26.

Campos, N. F. and Y. Kinoshita (2003), "Why does FDI go where it goes? New evidence from transition economies," International Monetary Fund Working Paper 03/288.

Chantasasawat, B., K.C. Fung, H. Lizaka, and A. Siu (2004), "Foreign direct investment in East Asia and Latin America," ADB Institute Discussion Paper 17.

Chitiga, M. and T. Kanderio (2003), "Trade openness and foreign direct investment in Africa," Department of Economics, University of Pretoria.

De Gregorio, J. (1992), "Economic growth in Latin America," Journal of Development Economics 39(1): 59-84. 
Galan, I.J. and J. Gonzalez-Benito (2006), "Distinctive determinant factors of Spanish foreign direct investment in Latin America," Journal of World Business 41(2): 171-89.

Garcia-Herrero, A. and D. Santabarbara (2005), "Does China have an impact on foreign direct investment to Latin America?" Retrieved from http://www. bis.org/repofficepubl/apresearchagh070424.pdf.

Gastanga, M.V., B. J. Nugent and B. Pashamova (1998), "Host countries reform and FDI inflows: How much difference do they make?" World Development 26(7): 1299-314.

Hernàndez, L. and F. Parro (2008), "Economic reforms, financial development and growth: Lessons from the Chilean experience," Cuadernos De Economia 45(131): 59-103.

Jaggers, K., M.G. Marshall, and T.R. Gurr (2004), "Polity IV Project," retrieved from www.systemicpeace.org/polity/polity4.htm).

Kobrin, J.S. (2005), "The determinants of liberalization of FDI policy in developing countries: A cross-sectional analysis, 1992-2001," Transnational Corporations 14(1): 1-38.

Kolstad, I. and E. Villanger (2008), "Foreign direct investment in the Caribbean," Development Policy Review 26(1): 79-89.

Love, J.H. and F. Lage-Hidalgo (2000), "Analysing the determinants of US direct investment in Mexico," Applied Economics 32(10): 1259-67.

Lensink, R. and O. Morrissey (2006), "Foreign direct investment: Flows, volatility and the impact on growth," Review of International Economics 14(3): 1-38.

McCord, G.C. and J. Sachs (2013), "Development, structure, and transformation: Some evidence on comparative economic growth," National Bureau of Economic Research Working Paper 19512.

Mulligan, C.B., R. Gil, and X. Sala-i-Martin (2004), "Do democracies have different public policies than nondemocracies?" Journal of Economic Perspectives 18(1): 51-74.

Ndikumana, L. and S. Verict (2007), "The linkages between FDI and domestic investment: Unraveling the developmental impact of foreign investment," Economics Department Working Paper Series, University of Massachusetts - Amherst.

Brame, R., P. Mazerolle, R. Paternoster, and A. Piguero (1998), "Using the correct statistical test for the equality of regression coefficients," Criminology 36(4): 859-66.

Quartey, P. and D. Tsikata (2007), "What key factors attract foreign direct investment to sub-Saharan Africa?" ISSER, University of Ghana.

Shatz, J.H. (2001), "Explaining foreign direct investment in the Andean countries," CID Working Paper 64, Harvard University.

UNCTAD (2011), World investment report 2011. Geneva: United Nations. 
Wang, Y. (2012), "Openness and productivity: The role of imports, FDI and international telecommunications," Latin American Journal of Economics 49(2): $125-45$.

Wooldridge, M.J. (2009), Econometric analysis of cross section and panel data. Cambridge: MIT Press.

Trevino, L.J., J.D. Daniels, and H. Arbelaez (2002), "Market reform and FDI in Latin America: An empirical investigations," Transnational Corporations II(1): 29-48. 


\section{APPENDIX}

Table 1A. Study sample of 68 countries

\begin{tabular}{|c|c|c|c|}
\hline SSA & LAC & ASIA & North Africa \\
\hline Benin & Bolivia & Bangladesh & Algeria \\
\hline Bostwana & Brazil & China & Egypt \\
\hline Burkina Faso & Chile & Indonesia & Morocco \\
\hline Cameroon & Colombia & Malaysia & Tunisa \\
\hline Central Africa & Costa Rica & Nepal & \\
\hline Congo, Dem. Republic & Ecuador & Pakistan & \\
\hline Congo, Republic & El Salvador & Philippines & \\
\hline Cote d'Ivoire & Guatemala & South Korea & \\
\hline Gabon & Guyana & Sri Lanka & \\
\hline Gambia & Haiti & Thailand & \\
\hline Ghana & Honduras & India & \\
\hline Guinea & Jamaica & Papua New Guinea & \\
\hline Guinea Bissau & Mexico & Singapore & \\
\hline Kenya & Nicaragua & & \\
\hline Madagascar & Paraguay & & \\
\hline Malawi & Peru & & \\
\hline Mali & Trinidad and Tobago & & \\
\hline Mauritania & Mozambique & & \\
\hline Mauritius & Uruguay & & \\
\hline Mozambique & Venezuela & & \\
\hline \multicolumn{4}{|l|}{ Niger } \\
\hline \multicolumn{4}{|l|}{ Nigeria } \\
\hline \multicolumn{4}{|l|}{ Senegal } \\
\hline \multicolumn{4}{|l|}{ Sierra Leone } \\
\hline \multicolumn{4}{|l|}{ South Africa } \\
\hline \multicolumn{4}{|l|}{ Swaziland } \\
\hline \multicolumn{4}{|l|}{ Tanzania } \\
\hline \multicolumn{4}{|l|}{ Togo } \\
\hline \multicolumn{4}{|l|}{ Uganda } \\
\hline \multicolumn{4}{|l|}{ Zambia } \\
\hline Zimbabwe & & & \\
\hline
\end{tabular}


Table 2A. Determinants of FDI in Asia

\begin{tabular}{|c|c|c|c|}
\hline Independent variables & Fixed effects & Random effects & GMM \\
\hline Trade $_{t-1}$ & $\begin{array}{c}0.016 \\
(0.016)^{* *}\end{array}$ & $\begin{array}{c}0.02 \\
(0.000)^{* * *}\end{array}$ & $\begin{array}{l}0.036 \\
(0.11)\end{array}$ \\
\hline Debt & $\begin{array}{c}-0.044 \\
(0.000)^{* * *}\end{array}$ & $\begin{array}{c}-0.022 \\
(0.015)^{* *}\end{array}$ & $\begin{array}{l}-0.049 \\
(0.345)\end{array}$ \\
\hline Growth $_{t-1}$ & $\begin{array}{c}0.015 \\
(0.679)\end{array}$ & $\begin{array}{c}0.025 \\
(0.464)\end{array}$ & $\begin{array}{l}0.361 \\
(0.17)\end{array}$ \\
\hline Infrastructure & $\begin{array}{c}0.005 \\
(0.000)^{* * *}\end{array}$ & $\begin{array}{c}0.005 \\
(0.000)^{* * *}\end{array}$ & $\begin{array}{c}0.000 \\
(0.975)\end{array}$ \\
\hline Inflation & $\begin{array}{c}-0.001 \\
(0.001) * * *\end{array}$ & $\begin{array}{c}-0.001 \\
(0.023)^{* *}\end{array}$ & $\begin{array}{c}-0.003 \\
(0.136)\end{array}$ \\
\hline Revolution & $\begin{array}{r}-0.022 \\
(0.93)\end{array}$ & $\begin{array}{c}0.122 \\
(0.596)\end{array}$ & $\begin{array}{c}1.433 \\
(0.309)\end{array}$ \\
\hline Constraints on executive & $\begin{array}{c}-0.105 \\
(0.209)\end{array}$ & $\begin{array}{c}0.026 \\
(0.675)\end{array}$ & $\begin{array}{c}-1.424 \\
(0.233)\end{array}$ \\
\hline Debt $\times$ ASIA & $\begin{array}{c}0.01 \\
(0.795)\end{array}$ & $\begin{array}{c}-0.01 \\
(0.701)\end{array}$ & $\begin{array}{l}-0.105 \\
(0.414)\end{array}$ \\
\hline Infrastructure $\times$ ASIA & $\begin{array}{c}-0.008 \\
(0.004) * * *\end{array}$ & $\begin{array}{c}-0.007 \\
(0.001)^{* * *}\end{array}$ & $\begin{array}{c}-0.012 \\
(0.098)^{*}\end{array}$ \\
\hline Growth $_{t-1} \times$ ASIA & $\begin{array}{c}0.013 \\
(0.909)\end{array}$ & $\begin{array}{c}0.071 \\
(0.423)\end{array}$ & $\begin{array}{c}-0.156 \\
(0.69)\end{array}$ \\
\hline Inflation $\times$ ASIA & $\begin{array}{c}-0.003 \\
(0.961)\end{array}$ & $\begin{array}{l}-0.048 \\
(0.415)\end{array}$ & $\begin{array}{c}0.042 \\
(0.867)\end{array}$ \\
\hline Constraints on executive $\times$ ASIA & $\begin{array}{l}0.229 \\
(0.18)\end{array}$ & $\begin{array}{c}0.048 \\
(0.674)\end{array}$ & $\begin{array}{c}2.192 \\
(0.288)\end{array}$ \\
\hline Observations & 290 & 290 & 290 \\
\hline \multicolumn{4}{|l|}{$R^{2}$} \\
\hline :within & 0.29 & 0.26 & \\
\hline :between & 0.2 & 0.4 & \\
\hline :overall & 0.19 & 0.31 & \\
\hline $\operatorname{AR}(1)$ & & & 0.15 \\
\hline $\operatorname{AR}(2)$ & & & 0.96 \\
\hline Hansen test & & & 0.91 \\
\hline
\end{tabular}

Notes: Dependent variable is FDI/GDP. ASIA indicator is 13 countries. *** significance at $1 \%$ level, ** significance at $5 \%$ level, and * significance at $10 \%$ level. All specifications include a constant. Interaction terms are statistically significant variables from Table 3. GMM includes full time indicators. $\mathrm{AR}(1)$ and $\mathrm{AR}(2)$ are first and second order serial correlation tests. The Hansen test is the test of instrument validity. There is no second order serial correlation and the instruments are valid. The Hausman test, p-value 0.00 and $\chi^{2} 29.93$, is significant: fixed effects is preferred. Estimates are based on robust standard errors. $P$-values are in parentheses. 
